\title{
Accounting disclosure, value relevance and firm life cycle: Evidence from Iran
}

\author{
Bita Mashayekhi ${ }^{1}$, Omid Faraji ${ }^{2}$, Arash Tahriri ${ }^{3}$ \\ ${ }^{1}$ Associate Professor of Accounting, Faculty of Management, University of Tehran, Tehran, Iran \\ ${ }^{2} \mathrm{PhD}$ Student of Accounting, Faculty of Management, University of Tehran, Tehran, Iran \\ ${ }^{3}$ Assistant Professor of Accounting, University of Tehran, Tehran, Iran
}

\section{Email address:}

mashaykhi@ut.ac.ir (B. Mashayekhi)

\section{To cite this article:}

Bita Mashayekhi, Omid Faraji, Arash Tahriri. Accounting Disclosure, Value Relevance and Firm Life Cycle: Evidence from Iran. International Journal of Economic Behavior and Organization. Vol. 1, No. 6, 2013, pp. 69-77. doi: 10.11648/j.ijebo.20130106.13

\begin{abstract}
In this study the effect of accounting disclosure on value relevance in different stages of firm life cycle has been investigated. In order to do so, 101 companies listed on the Tehran Stock Exchange (Iran) between years 2005 to 2011 were chosen as sample. The sample firms were classified into four stages in the life cycle as Introduction, growth, maturity and Shake-Out (decline), by taking benefit from the cash flows pattern as a proxy for firm life cycle. Then in each of these stages of life cycle, the firms were classified into as high or low disclosure quality. The results of regression in ordinary least squares and Wald Test methods (to examine the significance of difference in the adjusted R squares) indicate that the relation between earnings and changes in earnings with stocks return (value relevance model) among the high and low quality disclosing companies at each stages of the life cycle are not significantly different from each other.
\end{abstract}

Keywords: Accounting Disclosure, Value Relevance, Firm Life Cycle

\section{Introduction}

Considering the separation of ownership from control, accounting disclosure is a suitable mean to communicate the information between manager and external users. The need for accounting disclosure is the results of information asymmetry and agency problem between the management and investors (Healy \& Palepu, 2001). Enhanced disclosure results in a decrease in uncertainty concerning the future performance of company and facilitates the exchange of firm stock. Many of the previous studies have discussed the role and effect of accounting disclosure on the firm cost of capital, stocks liquidity and etc. (Botosan and Plumlee, 2002; Healy et al., 1999). Also, another study has discussed the value relevance through examining the relation of earnings, book value and stock prices (stock return) (Barth \& Clinch, 1996). Eventually, it may be implied from a variety of studies that one of the requirement of value relevance of accounting reports is the level and quality of accounting disclosure. High quality information and accounting disclosure may highly affect the stock pricing by investors thus performing research about the effects of accounting disclosure on the value relevance seems essential. Increasing focus on the investors' information needs result in improving value relevance of the information in financial statements (Gjerde et al, 2005). Therefore, we expect that the value of accounting information is increased by enhanced disclosure quality and level. Through accounting disclosure and under lack of information symmetry, the firms tend to communicate information about their good performance to the investors (signaling theory). Also, the managers tend to reduce their agency costs through high quality accounting disclosure (agency theory). However, the level and quality of accounting disclosure are subjected to other factors such as cost of preparation and presentation of information, proprietary costs resulted from losing competitive advantage, costs of legal claims and other conditions under which disclosure fails to be made completely and with high quality. Companies have different characteristics within the different stages of life cycle, which highly affect the value relevance and the measures of company performance. A variety of theories have focused on the effect of company life cycle on the company disclosure policies and its value relevance. The companies in the growth step may act in two ways concerning the accounting disclosure policies. To mitigate the risk of losing competitive advantage, these companies tend to give lower quality of disclosure and 
when their investment projects are completed, and so are entered into the maturity stages, they increase their disclosure quality (Piotroski 2003, Leuz 2004). However, the signaling theory predicts the opposite and shows that companies in the growth stages tend to communicate their desirable future performance through high quality accounting disclosure and as consequences the value relevance increases. In this study we try to examine different policies of accounting disclosure in the firm life cycle and its effects on value relevance. The study problem is that how companies in different life cycle stages may consider the value relevance and use different strategies regarding the quality of accounting disclosure? Or in other words, in which of life cycle stages the effect of accounting disclosure on the value relevance is more powerful? The rest of this paper is organized as follows: Section 2 provides the theoretical framework and literature. In Section 3, we discuss hypothesis development. Section 4 discusses the research design used to test these hypotheses. Section 5 analyzes the test results. Section 6 concludes with a summary of findings, an outline of this study's contributions, and suggestions for future research.

\section{Theoretical Framework and Literature Review}

\subsection{Disclosure Quality and Value Relevance}

Presenting relevant accounting information to investors and other users of financial statements may help them in making informed financial decisions. The conceptual framework published by the International Accounting Standards Board expresses that objective of financial statements is to "provide information about the financial position, performance and changes of financial positions of an entity that is useful to a wide range of users in making economic decisions" (IASB, 2001, par. 12). Therefore, any event that is likely to affect a company's current financial position or future performance should be reflected in its financial statements. Relevance is one of four principal qualitative characteristics that financial information should possess to be useful for decision making (IASB, 2001, par. 24). Financial statement information is relevant when it influences users' economic decisions by (a) helping them evaluate past, present, or future events relating to an entity and (b) confirming or correcting their past evaluations (IASB, 2001, par. 26).

The past studies have used the agency and signaling theories to explain the motivations of the management for accounting disclosure. According to signaling theory, companies with good performances tend to publish certain information, while other companies fail to follow such strategies. The companies may be able to present certain signs to investors on the good future performance through better disclosure in order to increase the value of their stocks. As a consequence the value relevance for such type of companies is high. According to agency theory, due to the separation of ownership from control, the managers are motivated to decrease agency costs through high quality disclosure and eventually the market price of stock will be closer to intrinsic value by high quality disclosure.

Studying the voluntary disclosure literature indicates that few studies have focused on usefulness of voluntary disclosure for the valuing company stocks. Lundhlm and Myers (2002) have explored whether enhanced disclosure information is incorporated in current stock price. Their findings show that companies with relatively more informative disclosures "bring the future forward" so that current stock returns reflect future earnings news more. Lundhlm and Myers suggest that a firm's disclosure activity reveals credible and relevant information in current earnings, and that this information is incorporated in the current stock price. Banghøj and Plenborg (2008) examine whether the level of voluntary disclosure have affected the association between current returns and future earnings. They conjecture that companies with a high level of value-relevant voluntary disclosures have a stronger association between stock returns and future earnings than companies with a low level of value-relevant disclosures. However, their results indicate that despite high level of voluntary disclosure, there is no relation between stocks return and future earnings. Their study raises the question of whether voluntary-disclosure information included value-relevant information about future earnings or whether market participants were not capable of incorporating voluntary-disclosure information in their equity valuations. Hassan et al (2009) have examined the association between the voluntary disclosure and value of company among the Egyptian companies. They found a positive and insignificant association between voluntary disclosure and firm value. Considering the results of above studies and balance between the costs and benefit of information disclosure, assessing the effect of level and quality of information provided by firm on value relevance seems necessary.

\subsection{Value Relevance, Disclosure Quality and Firm Life Cycle}

In this section we explore methods of classification and financial features of companies in each life cycle stages and eventually focus on current theories in the field of value relevance and disclosure quality considering the firm life cycle. Also, in accounting field some of the researchers have examined the effect of company life cycle on the accounting information disclosure. These researchers usually have introduced four stages to describe the company life cycle as per the following (Anthony and Ramesh 1992):

\subsubsection{Introduction Stage}

In this stage, usually the assets (company size) are limited, the cash flows resulted from the operating activities and earnings ability are in low levels and companies require high liquidity for finance and achieving 
growth opportunities. The dividend ratio in these firms is usually zero or maximum $10 \%$ and the return on investment or adjusted return on investment is sometimes negligible in comparison to the cost of capital.

\subsubsection{Growth Stage}

In this stage, the company size is bigger than companies in the introduction stage and the growth of sales and incomes is also faster than the introduction stage. Bigger financial resources are invested in the productive assets and the company enjoys more flexibility in the liquidity indexes. The dividend ratio in this kind of companies usually fluctuates between 10 and $50 \%$. Also the return on investment or adjusted return on investment often exceeds the cost of capital.

\subsubsection{Mature Stage}

In this stage the companies experience stable sales and the need for cash is mainly financed through internal sources. Also the size of these firms is bigger than the size of the firms in the growth stage. The dividend ratio in these companies usually fluctuates between 50 and 100\%. Due to the high level of liquidity and decreased dependency on the external finance, usually the return on investment or adjusted return on investment is equal or more than cost of capital.

\subsubsection{Shake-out and Decline Stage}

In this step, in case there are growth opportunities, most likely they are very limited and the proxy of earnings ability, liquidity and fulfillment of liabilities are of declining trend, and companies are under highly serious competitive conditions; meanwhile, the cost of capital is quite high, so that in most cases the return on investment or adjusted return on investment is less than cost of capital.

According to Myers (1977), firm value has two components: assets in place and growth opportunities. The information that accounting performance measures provide is expected to be different for each component. Because the proportion of these two value components differs in each lifecycle stage, the value-relevance of accounting performance measures is expected to vary stage by stage. In early life-cycle stages, growth opportunities are a larger component of firm value; in later stages, assets in place become a larger component. An important part of company's value in the introduction stage is due to future growth opportunities. In growth stage, the ratio of assets in place to the firm value is high but still growth opportunity forms an important part of the total firm value. In this part, the assets in place are more representative of the growth opportunities available to the firm and are now generating net income and operating cash flows. As mentioned earlier, the current theories and some of previous studies indicated that the high quality accounting disclosure has positive effect on the value relevance. The earnings in the growth stage do not provide certain information on the future cash flows of growth opportunities. Meanwhile, earnings provide little relevant information on the value of asset in place. Also earnings persistence for these firms is low, which limits the value relevance of earnings (Black, 1998). Eventually, we expect that in the early stages the company earnings has little value relevance and, the firm may use high quality accounting disclosure policies to indicate their future growth opportunities, to be able to signal the market on their desirable future performance. In growth stage, the firms are highly tended to make their stock price approach closer to their intrinsic value via high quality accounting disclosure. In other words, this issue may be addressed that the high quality accounting disclosure may be complementary to earnings and increasing the value relevance (signaling theory); meanwhile, we expect that the value relevance in the firms with high disclosure quality in the growth stage is more than firms with low disclosure quality.

In the mature stage, the value of the growth opportunities with respect to the assets in place is less than the previous stages. In this stage, the assets in place of the firm indicate the important part of firm value in the future and eventually, the firm usually has desirable disclosure level. However, this issue shall be considered that in this stage even the high quality accounting disclosure policies may not highly affect the firm value, as most of the firm value has been reflected in the assets in place. In the small sized firms, the accounting earnings in the mature stage become positive and enjoy higher relation with the firm value. Considering this issue, it is expected that the growth opportunities are not significant and accounting disclosure has little effect on the company value. In the decline and shake-out stage, the value of assets in place reflects a major part of firm value. The growth opportunities in this stage are limited and the firms had negative earnings, but the earnings reflect the reality of the company's economic situation, thus earnings persistence in these firms is higher (Black, 1998). This relation causes the firm market value to have a positive association with the earnings; in addition it seems that accounting disclosure may have a little effect on value relevance with respect to other stages.

In a study performed by Jenkins et al (2009), the value relevance of earnings in business cycles has been examined. They (quoted from Johnson, 1991) specified that the earnings response coefficients (ERC) within the economic expansion are higher than economic recession. They criticized Johnson's study on the grounds that no difference between the current earnings and expected earnings (next year earnings) was considered. Therefore, they considered the expected future earnings variable in their value relevance model. Finally, their results indicated that the value relevance of current year earnings within the economic recession is higher than economic expansion.

\section{Hypothesis Development}

Considering the issues addressed in study literature section, it is observed that considering their financial position, the firms select specific accounting disclosure 
policies within their life cycle. Regarding firm and growth stage, balance sheet and cash flow statement information may not reflect the firm value, so it is expected that the high quality accounting disclosure by company results in communicating useful information on the firm future earnings and so the value relevance is increased. In other words, it may be said that in the growth stage, the companies are tended to communicate useful information on the company future to the market through accounting disclosure and eventually increase its value relevance. Thus it is expected that due to high competition environment, the firm is not tended to communicate information to the firm's competitors through low quality accounting disclosure, so that the competitive advantage of company is not lost. In the other stage of life cycle such as mature, decline and shake-out, as the growth opportunities of company are rare and no information may be given to the investor in this regard through disclosure. As a result we expect that the accounting disclosure has little effect on the firm value. Considering the mentioned issues, the study hypothesis is expressed in the following:

There is a significant relationship between accounting disclosure quality and value relevance in different stages of firm life cycle.

\section{Data and Method}

\subsection{Data}

This study includes all companies listed to Tehran (Iran) Stock Exchange between 2005 and 2011; however study sample shall be made with respect to following limitations:

1 listed on Tehran Stock Exchange(TSE) prior to 2005,

2 For increasing comparability purposes, their fiscal term does no end on 20th of March,

3 Has no fiscal year change and operational interruptions within the aforementioned years,
4 Considering utilization of stock returns, the firm stocks have been transacted at least once a year.

5 Due to the difference of activities and accounting policies, it is not any financial brokerage, holding and bank industries.

Considering the limitations, 101 companies were chosen as study sample.

\subsection{Research Model}

In the previous studies made in Iran and other countries, mainly "Anthony and Ramesh Model" classification of firm-years to the life cycle different stages was used. In this study the model introduced by Dickinson (2011) is used (Table 1). This model, incorporates the cash flow patterns obtained based on previous studies, sign of cash flows resulted from operating, investing and financing activities are predicted in each of different company life cycle stages. In Iranian national accounting Standard No. 2, the cash flow statement is classified into five categories: 1) cash flow resulted from operating activities, 2) cash flow resulted from investments return and payments for finance, 3) cash flow resulted from tax, 4) cash flow resulted from investing activities and 5) cash flow resulted from finance activities. As we have used Dickinson Model, which is based on the cash flows sign according to three categories of cash flows (FASB standards); we have adjusted the firm cash flows statements and converted them based on FASB standards.

Considering that the life cycle is classified into five stages of introduction, growth, mature, shake-out and decline, therefore the companies' annual grouping model shall be as per the following. We use these models to classify the entire firm-year into four groups of introduction, growth, mature and decline (shake-out). Based on previous studies and due to high similarity, we consider the decline and shake-out stages similar.

Table 1. predicted sign of different category of cash flow in different life cycle stages

\begin{tabular}{lccccccccc}
\hline & 1 & 2 & 3 & 4 & 5 & 6 & 7 & 8 \\
\cline { 2 - 9 } & Introduction & Growth & Mature & Decline & Decline & Decline & $\begin{array}{c}\text { Shake- } \\
\text { Out }\end{array}$ & $\begin{array}{c}\text { Shake- } \\
\text { Out }\end{array}$ \\
\hline Cash Flow Resulting From operating Activities & - & + & + & - & + & + & - & - \\
Cash Flow Resulting From Investing Activities & - & - & - & - & + & + & + & + \\
Cash Flow Resulting From financing Activities & + & + & - & - & + & - & + & - \\
\hline
\end{tabular}

Then we categorize the firm-year within each cycle into two groups of high and low quality of disclosure considering the median of the mandatory disclosure scores published by Tehran Stock Exchange. The company disclosure quality scores have been calculated based on the publishers information score with respect to their reporting status in terms of reliability and timeliness of sending the information.

We used the model presented by Easton and Harris (1991) to investigate the research hypothesis.

$$
\operatorname{RET}_{\mathrm{it}}=\beta_{0}+\beta_{1} \mathrm{EARN}_{\mathrm{it}}+\beta_{2} \Delta \mathrm{EARN}_{\mathrm{it}}+\mathrm{e}_{\mathrm{it}}
$$

The dependent variable of this model is return (RET) and the independent variables include earnings (EARN) and earnings changes $(\triangle \mathrm{EARN})$. The method of measuring the variables of this model includes:

$\mathrm{RET}_{\mathrm{it}}$ : return of firm $\mathrm{i}$ in year $\mathrm{t}$

EARN $_{\mathrm{it}}$ : earnings of firm $\mathrm{i}$ in year $\mathrm{t}$ deflated by the firm market value of firm 
$\triangle E A R N_{i t}$ : changes of earnings of firm i from yeat t-1 to year $t$ deflated by the firm market value of firm

Accounting earnings are considered value relevant if there is an association between returns and earnings significance reflected in positive levels and earnings change coefficients. Especially, summation of $\beta 1$ and $\beta 2$ coefficients is equal to the earnings response coefficient (ERC) and the adjusted R-squared of this model is measured as value relevance. Higher accounting earnings are relevant to the stocks return and impacts firm stock returns.

\section{Results}

First of all the companies were classified according to cash flow proxy model into different categories of life cycle stages and then the median of the firm mandatory disclosure scores have been calculated for each of these stages and categorized into high and low disclosures. After that, the value relevance model posed in the previous part, estimates high and low categories within each stages and the difference between the model adjusted R-squared for each firm-year existed in the high and low quality disclosure levels are examined through Wald test. First of all, the descriptive statistics for the study variables shall be mentioned separately for the life cycle stages.

\subsection{Descriptive Statistics}

The results of descriptive statistics for each variable have been given separately for each of life cycle stages. As it may be seen in the table, the average of firm mandatory disclosure scores in companies which are in mature stages is more than other stages. Meanwhile, the return of firms in decline and shake-out stages is more than others. The relevant reason may be that the firm's dividend for the investors due to lack of investment opportunities is higher, which causes increased return of these companies. The other significant point is that the average of earnings companies in mature stages is higher than other companies.

Table 2. Descriptive Statistic

\begin{tabular}{|c|c|c|c|c|c|}
\hline Life Cycle & Variable & Mean & Median & Minimum & Maximum \\
\hline \multirow{4}{*}{ Introduction } & Return & .145 & .0193 & $0.975-$ & 7.57 \\
\hline & Earnings & .0579 & .0509 & -.31 & .49 \\
\hline & Earnings Changes & -.0613 & -.0031 & -3.61 & 1.47 \\
\hline & Disclosure Quality & 41.47 & 41.14 & -1.00 & 94 \\
\hline \multirow{4}{*}{ Growth } & Return & .0934 & .0659 & -.953 & 2.41 \\
\hline & Earnings & .1046 & .0934 & -.12 & .32 \\
\hline & Earnings Changes & -.0022 & .0030 & -.46 & .48 \\
\hline & Disclosure Quality & 48.8 & 46.0 & 4 & 98 \\
\hline \multirow{4}{*}{ Mature } & Return & .23 & .16 & -.99 & 2.94 \\
\hline & Earnings & .45 & .13 & -.26 & 10.1 \\
\hline & Earnings Changes & -.13 & .01 & $0.39-$ & .47 \\
\hline & Disclosure Quality & 52.93 & 55.60 & -1 & 98 \\
\hline \multirow{4}{*}{$\begin{array}{l}\text { Decline And } \\
\text { Shake-Out }\end{array}$} & Return & .36 & .25 & -.87 & 2.9 \\
\hline & Earnings & .1427 & .1261 & -.54 & .63 \\
\hline & Earnings Changes & -.0159 & .0169 & -5.14 & .47 \\
\hline & Disclosure Quality & 51.5 & 55.1 & -13 & 97 \\
\hline
\end{tabular}

\subsection{Results of Regressions}

In table 3, the results of estimating model for the introduction stage with ordinary least squares (OLS) method has been presented for two classes of high and low quality disclosure firms. As it is seen in panels A and B of table 3 , both models are linear and Durbin-Watson statistics indicates lack of autocorrelation of the residuals. In low quality disclosure firms, the earnings changes variable is statistically significant in the level of less than 1 percent and the adjusted R-squared of the model is equal to $18.2 \%$, which indicates the explanatory nature of the company earnings for the return variable. Meanwhile, in high quality disclosure companies, the accounting earnings variable is statistically significant in the level of less than 5 percent and the adjusted R-squared for the low quality disclosure companies is equal to 0.106 . The difference between the coefficients explanatory power of these two model and adjusted R-squared has been examined by Wald statistics, while Chi Square statistics relevant to Wald test is not meaningful, so this indicates that the value relevance in high and low quality disclosure companies have no significant difference with each other.

In table 4 , the results of estimating regression model have been given for the growth stage. The earnings changes variable in the 0.05 error level and the accounting earnings variable in the 0.1 error level are significant for the low quality disclosure companies in panel A of table 4. Also, the 
adjusted R-squared is equal to 0.133 . Meanwhile, in panel $\mathrm{B}$ of table 4 , the value relevance of the companies with high disclosure quality has been presented which indicates the earnings changes variable has statistically significant coefficient and the adjusted R-squared of this model is equal to $19.1 \%$. The Wald statistics for the difference between the R-squared is statistically insignificant and eventually, there is no meaningful difference between the adjusted determination coefficients in the high and low quality companies. However, it should be considered that the adjusted R-squared in the high quality disclosure companies in growth stage is more than the same for the low quality disclosure companies. Other information on some of the classical linear regression model assumptions has been mentioned in the following tables and no problem may be seen regarding the same.

Table 3. The result of hypothesis testing

\begin{tabular}{|c|c|c|c|c|}
\hline \multicolumn{5}{|c|}{ Panel A: Introduction stage Companies with low disclosure quality } \\
\hline Variable & Standard coefficient & t statistic & Sig & VIF \\
\hline intercept & .120 & 2.036 & .046 & \\
\hline EARN & -.003 & -.023 & .982 & 1.014 \\
\hline$\triangle \mathrm{EARN}$ & .458 & $\begin{array}{c}3.832 \\
\mathrm{R}^{2}: .209 \\
\text { Adjusted } \mathrm{R}^{2}: .182 \\
\text { F statistic: } 7.800 \\
\text { Sig of F statistic: } .001 \\
\text { DW statistic: } 1.81\end{array}$ & .000 & 1.014 \\
\hline \multicolumn{5}{|c|}{ Panel B: Introduction stage Companies with high disclosure quality } \\
\hline Variable & Standard coefficient & t statistic & Sig & VIF \\
\hline intercept & .094 & .583 & .562 & \\
\hline EARN & .273 & 2.160 & .035 & 1.036 \\
\hline$\triangle \mathrm{EARN}$ & .174 & 1.379 & .173 & 1.036 \\
\hline & & $\begin{array}{c}\mathrm{R}^{2}: .135 \\
\text { Adjusted } \mathrm{R}^{2}: .106 \\
\text { F statistic: } 4.689 \\
\text { Sig of F statistic: } .013 \\
\text { DW statistic: } 2.053\end{array}$ & & \\
\hline
\end{tabular}

Table 4. The result of hypothesis testing

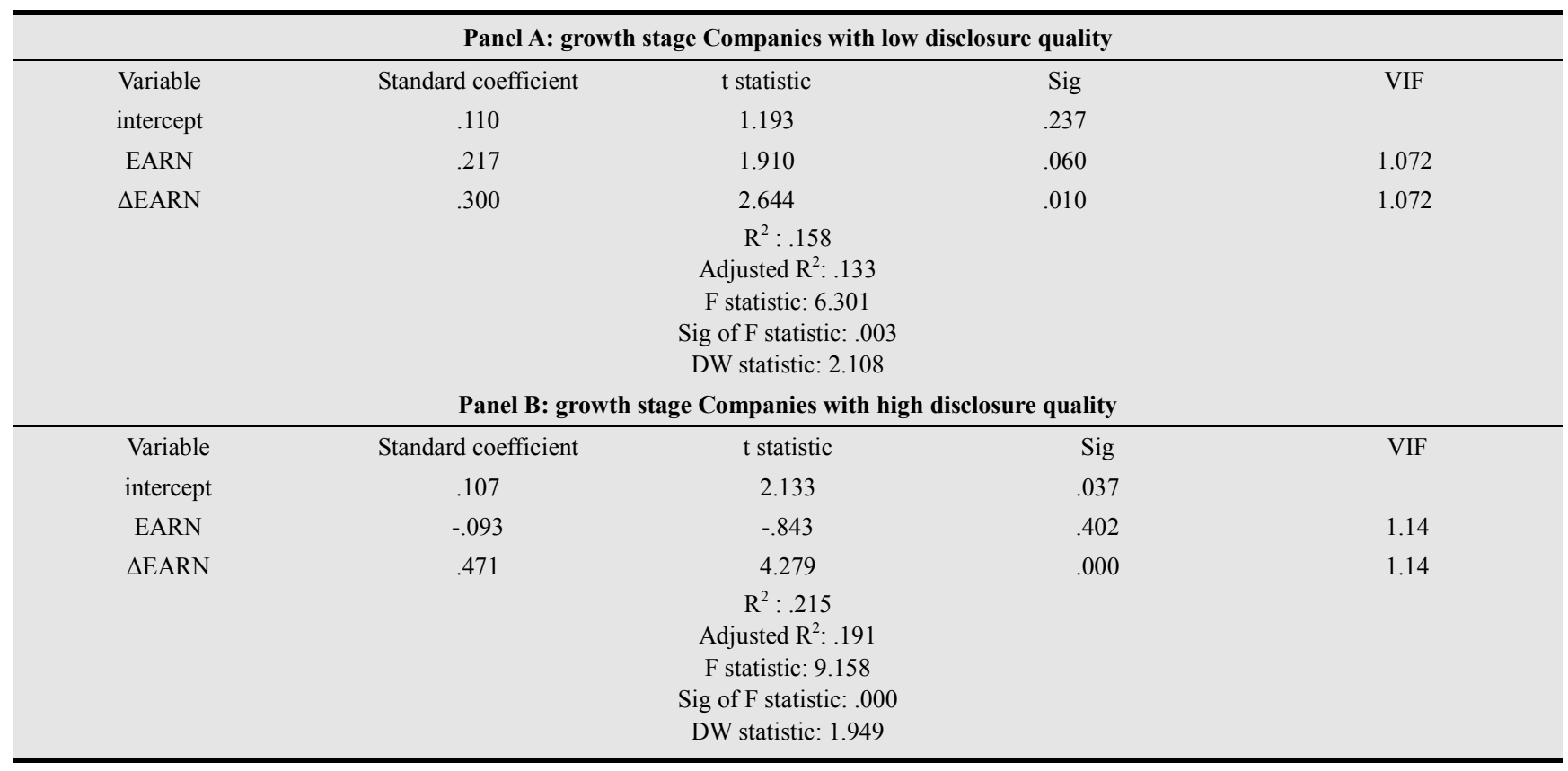

Estimating the regression model for the mature stage has been given panels A and B of table 5. In panel A of the table, for the low quality disclosure companies, merely the company earnings changes variable is statistically significant in less than 1 percent error level and the adjusted R-squared is equal to $16.8 \%$. Meanwhile, in panel $\mathrm{B}$ of table 5 relevant to high quality disclosure companies, the accounting earnings and accounting earnings changes variables are 


\section{Conclusion}

In this study we examined the effect of accounting disclosure on the value relevance in different company life cycle stages. The firms in their different stages of life cycles are tended to follow different policies on accounting disclosure considering their financial conditions and motivations. Therefore, in this study we examined the issue of how value relevance in each of the firm life cycle stages is and how each of firms with different accounting disclosure quality may increase the accounting earnings usefulness to affect the firm stock returns. Eventually, we categorized the firm-year existed in the study sample based on Dickinson cash flows proxy(2011) separately, into four stages of introduction, growth, decline and shake-out. Then, based on the median of firm disclosure quality scores in each stage of the firm life cycle, we classified the firm-years into two categories of high and low quality disclosure.

The results of study shows that for high quality disclosure firms in introduction, mature, decline and shake-out stages the disclosure qualities have less value relevance (e.g. adjusted determination coefficient for the return model) in comparison to the low quality disclosure firms. In order to study the statistical significance of difference of value relevance in the high and low quality disclosure firms in each of the cycles, we used the Wald test. The specified results of such test indicate that in none of the introduction, mature, decline and shake-out stages, there is a statistical significance difference between the adjusted R-squared of the value relevance model of low and high quality disclosure firms. Meanwhile, the results of regression model for the firms in growth stage indicates that the high quality disclosure firms have higher value relevance (adjusted R-squared) than the low quality disclosure firms, and in certain manner, the companies in this part are tended to communicate their desirable status and future growth opportunities to the market. These firms are tended to accentuate the earnings and unexpected earning through high quality disclosure to highly affect on the firm stock returns. In other words, as Myers (1977) addressed, the company value is equal to company assets in place and growth opportunities. Eventually, the growth firms are tended to communicate an extensive part of the value which is embedded in their growth opportunities through high quality accounting disclosure to the market, and eventually increase accounting earnings usefulness. However the adjusted R-square of high quality disclosure firms in the growth stage was more than the same for the low quality disclosure firms, but Wald test does not show the significant difference between the adjusted R-squared. Finally, the research hypothesis, based on the effect of accounting disclosure on the value relevance in each of the stages of life cycle is not confirmed. One of the important limitations in this study is that the firm disclosure scores published by Tehran Stock Exchange are related to the mandatory disclosure of the firms at stock exchange. In this study, we did not examine the effect of voluntary disclosure quality of the firms.

At the last run, the following suggestions are addressed for the future studies:

1 In future studies, the Ohlson price model (1995) may be used which is posed to examine the value relevance of accounting earnings and book value of ownership equity and their effect on the stock prices.

2 Also, it seems that it is possible to increase the model feasibility by adjusting Ohlson model (1995) and adding company disclosure variable in this model and also consider the effect of accounting disclosure on the company price stocks in addition to book value and accounting earnings and further examine the value relevance in each of company life cycle stages considering such adjusted model.

3 Taking benefit from artificial neural network techniques for determining the explanatory earnings variables and earnings changes to forecast the return and comparing the same with the linear models in each of the company life cycles and in the different levels of accounting disclosure quality is another approach which may be used in the future studies.

\section{References}

[1] Anthony J. H., Ramesh K. ( 1992). Association between Accounting Performance Measures and Stock Prices A test of the life cycle hypothesis . Journal of Accounting and Economics; 15: 203-27.

[2] Banghøj, J. and T. Plenborg. (2008). Value relevance of voluntary disclosure in the annual report. Accounting and Finance 48(2): 159.

[3] Barth, M. and G. Clinch. (1996). International accounting differences and their relation to share prices: Evidence U.K., Australian, and Canadian firms. Contemporary Accounting Research 13(1): 135.

[4] Black E.L.(1998). Life-Cycle Impacts on the Incremental Relevance of Earnings and Cash flow Measures. Journal of Financial Statement Analysis; 40-56.

[5] Botosan, C. A., \& Plumlee, M. A. (2002). A re-examination of disclosure level and the expected cost of equity capital. Journal of Accounting Research, 40(1), 21-40.

[6] Dickinson, V.(2011). cash flow patterns as a proxy for firm life cycle, accounting review, Vol. 86, No. 6, pp. 1969-1994

[7] Easton, P. and T. Harris. (1991). Earnings as Explanatory Variables for Returns. Journal of Accounting Research, Vol. 29 (Spring), pp. 19-36.

[8] Gjerde, O., K. H. Knivsflå, et al. (2005). The Value-Relevance of Financial Reporting on the Oslo Stock Exchange over the Period 1964-2003. Discussion Papers 2005/23, Department of Finance and Management Science, Norwegian School of Economics and Business Administration.

[9] Hassan, O., P. Romilly, et al. (2009). The value relevance of disclosure: Evidence from the emerging capital market of Egypt. The International Journal of Accounting 44(1), 79. 
[10] Healy, P. M., Hutton, A. P., \& Palepu, K. G. (1999). Stock performance and intermediation changes surrounding sustained increases in disclosure. Contemporary Accounting Research, 16(3), 485-520.

[11] Healy, P. \& Palepu, K. ( 2001).Information Asymmetry, Corporate Disclosure, and the Capital Markets: A Review of Empirical Disclosure Literature. Journal of Accounting and Economics, 31, 485-520.

[12] IASB (2001). International Accounting Standards Board, Framework for the Preparation and Presentation of Financial Statements. IASB, London, UK.

[13] Jenkins David S., Kane Gregory D. and Velury Uma (2009).Earnings Conservatism and Value Relevance Across the Business Cycle. Journal of Business Finance \& Accounting.
[14] Leuz, C.(2004). Proprietary Versus Nonproprietary Disclosures: Evidence from Germany, in Leuz C., D. Pfaff and A. Hopwood.The Economics and Politics of Accounting

[15] Lundholm, R. and L. Myers (2002). Bringing the future forward: The effect of disclosure on the returns-earnings relation. Journal of Accounting Research, 40(3): 809.

[16] Myers, S.C. (1977).Determinants of Corporate Borrowing. Journal of Financial Economics, 5, pp. 147-175.

[17] Ohlson, J. A. (1995). Earnings, book values, and dividends in equity valuation. Contemporary Accounting Research 11(2): 661 .

[18] Piotroski, J. (2003). Discretionary Segment Reporting Decisions and the Precision of Investor Beliefs. Working Paper, University of Chicago. 